\title{
PEMIKIRAN KALIGRAFI ARAB DI INDONESIA
}

\author{
M. Farkhan Mujahidin \\ farchanmd@yahoo.com \\ Program Studi Sastra Arab
}

Fakultas Ilmu Budaya Universitas Sebelas Maret Surakarta

\begin{abstract}
Arabic calligraphy as an art form distinctively Islamic in its development continues to progress, both in terms of form, writing, style, visualization, and media usage trends. Research on Arabic calligraphy is intended to determine the development of Arabic calligraphy in Indonesia by presenting a glimpse of history in the Middle East until in Indonesia. Data were obtained from a review of literature and direct observation, as well as the sources of literature and internet, studies done using qualitative methods based on quantitative data obtained. Results showed that the development of Arabic calligraphy in Indonesia towards metamorphosis, transformation and paradigm forms in accordance with the spirit of the age. Changes in cultural traditions characterized by the development of civilization increasingly open and reveal that calligraphy in Indonesia continues to grow following the movement of culture in other aspects of the broader, he was instrumental not only in the frame of the architecture of religious buildings, but he has been included in the development of eco-architecture today central to the social needs of society.
\end{abstract}

Keywords: cultural, social and religious heritage, the transformation of the form.

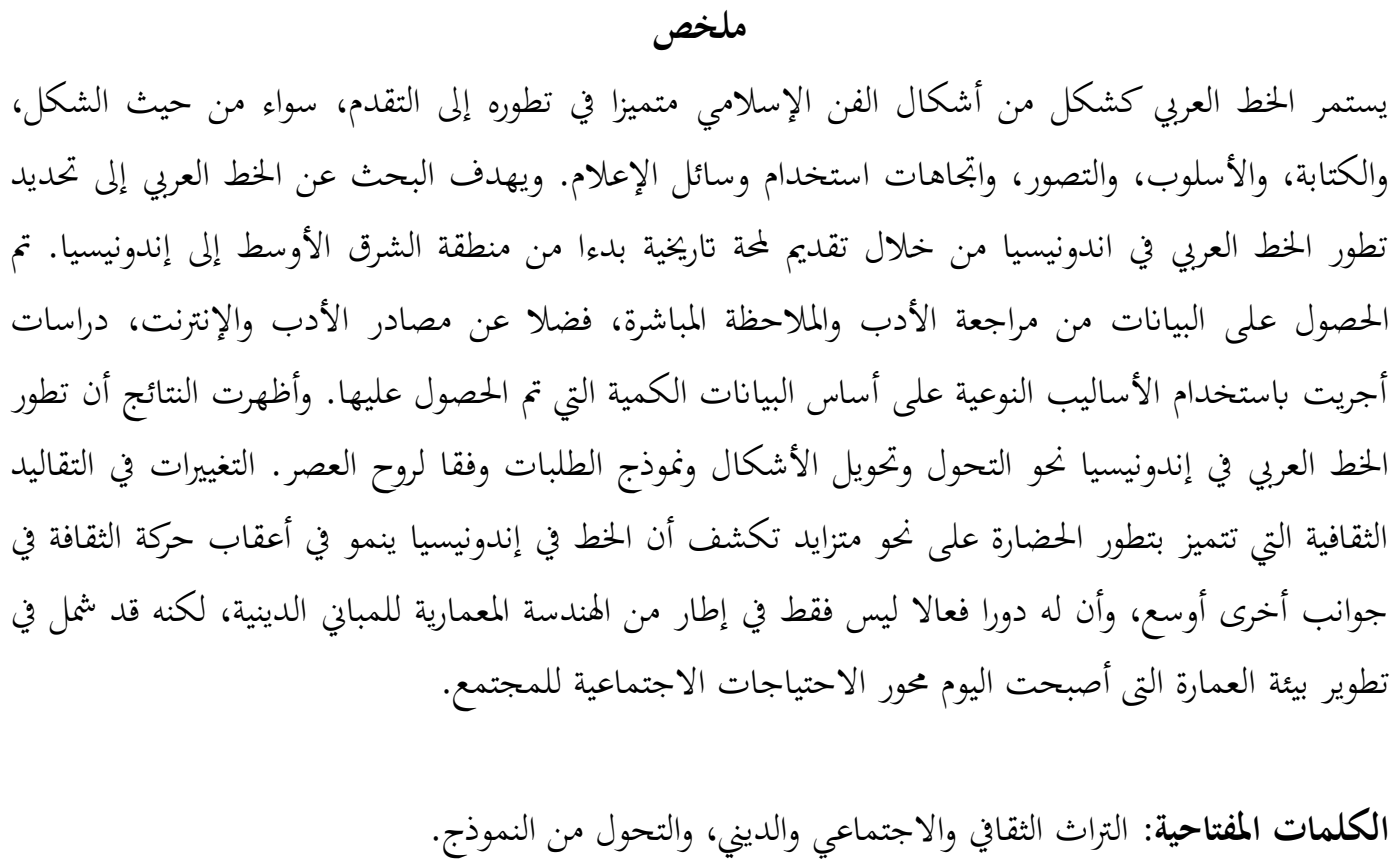




\section{Pendahuluan}

Kaligrafi di dalam berbagai literatur sering dipahami sebagai seni menulis indah, yaitu menulis sesuai dengan aturan atau kaidah menulis, atau melukis huruf yang ditujukan sebagai hiasan tulis. Di Indonesia, perkembangan kaligrafi tidak terbatas pada jenis tulisan tertentu, ada kaligrafi Arab, China, Jawa, Jepang, dan lain sebagainya. Masing-masing memiliki kekhasan dan karakteristik sesuai dengan sejarah dan budayanya. Setidaknya setiap jenis kaligrafi yang dimiliki masyarakat dari berbagai wilayah memiliki fungsi keindahan dan menjadi sarana penampakan atas pesan-pesan metafisis yang tersurat di dalam budayanya.

Di Indonesia kaligrafi menjadi bagian penting dalam kehidupan keagamaan, sosial, politik, dan budaya, karena pentingnya bidang kesenian ini kaligrafi Arab selalu menjadi perhatian, pengetahuan dan kemahiran di kalangan umat islam. Hal ini juga tidak terlepas dari pesan yang disampaikan oleh Rasulullah Muhammad SAW: 'alaikum bi chusni alkhaththi fainnahū min mafātīchi ar-rizqi. (عليكم بحسن الخط فإنه من مفاتح الرزق) "Hendaklah kalian memperindah tulisan, karena keindahan tulisan itu membuka pintu rejeki." Khalifah keempat Ali bin Abi Thalib juga mengatakan bahwa tulisan indah yang dikerjakan oleh seseorang tidak sekedar menambah kemampuan kreatifitas estetis tetapi pekerjaan itu membuka pintu rejeki bagi pelakunya. Pesan-pesan tersebut nampaknya sangat kuat bagi mereka yang mempunyai jiwa dan pengalaman seni yang bernafas keruhanian, di samping bahwa seni itu juga menjadi bukti sejarah yang terus dikenang karena nilai keindahan yang muncul di dalamnya bagaikan perhiasan yang tidak ternilai harganya. tulisan indah itu merupakan kepandaian hati yang ditampakkan oleh alat-alat jasmaniah, jika kalian memperbaiki pena berarti memperbaiki tulisan, dan jika mengabaikan pena berarti mengabaikan tulisan. (ansharmtk.blogspot.com/.../sejarahperkembangan-kaligrafi-islami.html)
Kaligrafi Arab adalah wujud seni budaya Arab, pengaruhnya sangat luas bagi masyarakat dunia. Seni Arab ini tumbuh dan berkembang sebagai wujud simbol budaya bangsa Arab yang menyebar sampai ke wilayah-wilayah yang telah ditaklukkan ketika agama Islam disebarkan atau wilayah-wilayah yang telah terpengaruh oleh kekuasaan Islam. Jika merujuk kepada masa kejayaan Islam, kaligrafi yang dikembangkan pada masa Rasulullah SAW dapat bertahan kuat karena di dalam sebagian besar isinya memuat pesan-pesan ajaran agama yang ada di dalam Al-Quran maupun hadis. Kaligrafi Arab yang sebagian besar memuat pesan-pesan ajaran Islam tidak pernah berhenti , namun perkembangannya diteruskan oleh para sahabat dan orangorang muslim zaman pemerintahan islam, sejak daulah Umayyah, Abbasyiah, kerajaan Mughal, Andalus dan lain sebagainya hingga ke wilayah Asia. Hal ini menunjukkan hubungan yang kuat dan mudah berasimilasi antara seni ini dengan budaya setempat

Di Indonesia seni kaligrafi Arab memiliki sejarah tersendiri, kesenian ini masuk bersamaan dengan masuknya ajaran Islam yang dibawa oleh orang-orang keturunan Arab dan mengalami proses akulturasi dengan budaya setempat. Melalui budaya dan pendidikan yaitu dengan diajarkannya ajaran Islam dan ilmu-ilmu bahasa Arab, kaligrafi dengan sendirinya mengalami proses perkembangan yang sangat cepat dibanding tradisi kaligrafi lokal .

Secara teoritis sejarah kaligrafi Arab pada awalnya berupa garis atau goresan, kemudian berkembang menjadi tulisantulisan di berbagai media seperti batu, kulit, logam, kayu, dan benda-benda lain yang mempunyai fungsi administrasi, misalnya penggunaan stempel, surat menyurat atau naskah perjanjian di dalam sistem pemerintahan dan masyarakat. Tujuannya adalah untuk memenuhi kebutuhan administrasi dan informasi bagi generasi mendatang. Namun dalam perkembangannya fungsi itu bertambah atau berubah ke arah seni estetis, yaitu fungsi yang mengedepankan unsur keindahan dengan berbagai model dan 
coraknya, lewat fungsi ini kaligrafi menjadi ikon kesenian Arab yang dapat dijumpai pada bangunan bersejarah, tembok-tembok masjid, museum, dan berbagai artefak budaya manusia yang terpengaruh oleh kebudayaan Arab.

Memasuki abad modern fungsi dan peran kaligrafi mulai mengalami perubahan, jika pada masa lalu kaligrafi berfungsi sebagai sarana komunikasi, administrasi, dan estetika, namun dalam perkembangannya seni ini sudah mengarah kepada tujuan-tujuan yang sifatnya komplementer. Di Indonesia kaligrafi Arab juga mengalami metamorfosis dari fungsifungsi yang sudah ada sebagaimana tersebut di atas menjadi bentuk kesenian terpadu dengan kesenian lain, bahkan model kaligrafi Arab dengan bentuk representasi figural berupa gambar hewan dan tanaman digunakan untuk memberikan daya visual yang kuat seperti yang terdapat dalam berbagai bentuk kaligrafi Arab masa kini, suatu kreativitas yang juga dimunculkan di dalam kaligrafi jawa untuk merepresentasikan tokoh pewayangan.

Unsur-unsur zoomorfik di dalam kaligrafi Arab di Indonesia juga terlihat dalam berbagai macam ekspresi, unsurunsur ini nampaknya menarik untuk diteliti karena tidak sekedar dipahami sebagai

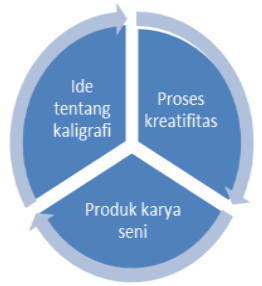

wujud penampakan visual. Di sisi lain wujud representasi dari unsur unsur ini menarik diteliti karena dengan metode naturalisasi ini tidak menutup kemungkinan akan timbulnya perbedaan pemahaman ideologis khususnya yang berkaitan dengan penafsiran ajaran Islam dalam hal penciptaan seni yang menghadirkan unsur-unsur makhluk hidup dan non makhluk hidup. Di sini persoalan bagaimana interpretasi dalam memahami doktrin atau sumber-sumber keagamaan diperlukan untuk memahami pesan-pesan artistik yang dimunculkan dalam seni kaligrafi. Persoalan yang menyangkut perkembangan budaya selanjutnya adalah bahwa kaligrafi itu bukan semata artefak seni namun juga melibatkan gagasan dan proses yang selalu dikembangkan dari satu wilayah ke wilayah lain dan dari satu budaya ke budaya yang lain dengan tidak meninggalkan arabisme sebagai asal usulnya. Terdapat banyak aspek yang mempengaruhi perkembangan seni ini sebagai aktivitas budaya, sosial, agama, dan politik yang akan memainkan kaligrafi di dalam kancah kehidupan manusia.

\section{Metodologi dan Kerangka Teori}

Artikel ini akan membahas pemikiran seni kaligrafi Arab sebagai ekspresi sosial dan budaya orang-orang Islam di Indonesia. Metode yang digunakan dalam melihat permasalahan budaya seni kaligrafi adalah: Pertama, pendekatan historis dengan menghubungkan kepada agama sebagai sumber budaya. Langkahlangkahnya adalah mengkaji sejarah asal muasal seni yang tumbuh dari Timur Tengah hingga menyebar ke berbagai wilayah di Indonesia. Sudut pandang ini juga mengkaji bagaimana proses sosial budaya kaligrafi menjadi cultural activity, atau aktifitas budaya keagamaan yang dikembangkan para seniman, pelajar, dan mahasiswa di pesantren, madrasah, dan perguruan tinggi. Kedua, pendekatan estetik religius, yakni melihat bagaimana tulisan dan lukisan kaligrafi dipahami dan dikaji sebagai objek estetika melalui pendekatan esoterik keagamaan ketika proses sosial budaya bertemu (ArabIndonesia).

Teori yang digunakan untuk menjelaskan perkembangan budaya ini adalah teori persebaran budaya atau difusi. Teori ini menjelaskan, bahwa: "Suatu kebudayaan dimaknai sebagai persebaran kebudayaan yang disebabkan adanya migrasi manusia. Perpindahan dari satu tempat ke tempat lain, akan menularkan budaya tertentu. Hal ini akan semakian tampak dan jelas kalau perpindahan manusia itu secara kelompok dan atau besar-besaran, di kemudian hari akan menimbulkan difusi budaya yang luar biasa. Setiap ada persebaran kebudayaan, di situlah terjadi penggabungan dua kebudayaan atau lebih. Akibat pengaruh kemajuan teknologi-komunikasi, juga akan mempengaruhi terjadinya difusi budaya. 
Keadaan ini memungkinkan kebudayaan semakin kompleks dan bersifat multikultural. Dengan adanya penelitian difusi, maka akan terungkap segala bentuk kontak dan persebaran budaya sampai ke wilayah yang kecil-kecil. Dengan demikian dapat dikatakan bahwa kontribusi pengkajian difusi terhadap kebudayaan manusia bukan pada aspek historis budaya tersebut, melainkan pada letak geografi budaya dalam kewilayahan dunia."

http://Prof.Dr.I Made Titib.blogspot.com.)

Berpijak dari teori persebaran itu penulis memahami mengapa kaligrafi Arab begitu cepat menyebar ke berbagai wilayah, Hal itu disebabkan karena sejak abad ke 13-14 banyak orang-orang Indonesia yang melakukan kontak budaya dengan wilayah Timur Tengah dan melakukan asimilasi serta akulturasi dalam bidang sosial dan ideologi. Pengetahuan dan peradaban adalah yang mempengaruhi hal ini, kemudian Islam dengan kitab suci Al-Quran dan hadis menjadi sebab lain karena dipandang memberikan orientasi kehidupan di samping kekuatan estetika yang ada di dalam agama itu.

Peradaban-peradaban besar yang pernah ada di masa lampau merupakan hasil persebaran yang berasal dari Mesir. Hal ini karena berdasarkan kajian keduanya, pernah terjadi suatu peristiwa difusi yang sangat besar di masa lampau yang berpusat di Mesir. Persebaran dari titik utama di Mesir ini kemudian bergerak ke arah timur yang meliputi daerah-daerah terjauh seperti India, Indonesia dan Polinesia hingga mencapai Amerika. Orang-orang Mesir yang disebut dengan 'putra-putra dewa matahari' ini melakukan perpindahan dengan cara menyebar ke berbagai tempat tersebut dalam usaha mereka untuk mencari logam mulia dan batu mulia seperti emas, perak dan permata. (Ahimsa-Putra, hal. 9)

Dalam karya monumentalnya, The Cultural Atlas of Islam, Al Faruqi bersama isterinya Louis Lamya telah menunjukkan persebaran kaligrafi dari barat ke timur pada abad ke tujuh sampai abad ke dua puluh ke dalam kelompok-kelompok hierarkhis berdasarkan kesatuan sub wilayah. Wilayah I sampai wilayah VII merupakan daerah persebaran seni kaligrafi di Timur Tengah, India, hingga Asia Timur dengan berbagai ragam dan coraknya. Wilayah VII adalah Asia Timur yang mencakup wilayah China Turan Xian, Kuala Lumpur, Kuala Kangsar, Banda Aceh, Jakarta, Samudra Pasai, Riau, Yogyakara, Solo, Semarang, Demak, Bandar Seri begawan, Singapora, Seoul, dan lain sebagainya. Peta ini menunjukkan difusi kaligrafi Timur tengah ke berbagai wilayah Asia-Afrika;

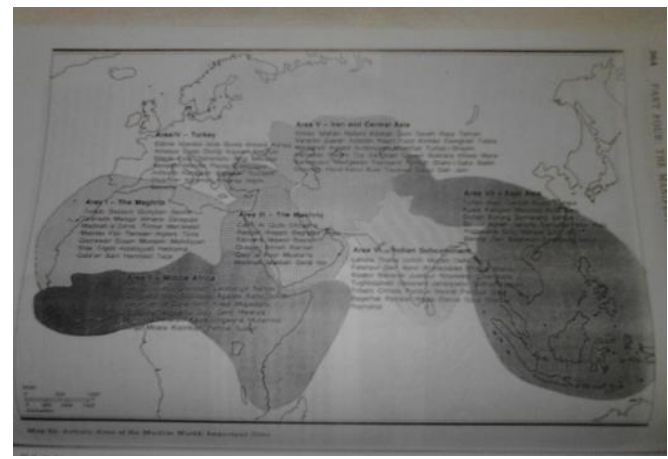

Gambar diambil dari : map 62 dalam The Cultural Atlas Of Islam karya Al Faruqi

\begin{tabular}{|c|c|}
\hline Wilayah & Negara \\
\hline $\begin{array}{l}\text { Wilayah I } \\
\text { ( Maghrib) }\end{array}$ & $\begin{array}{lr}\text { Maritania, } & \text { Maroko, } \\
\text { Algeria, } & \text { Tunisia, } \\
\text { Libya, } & \text { Spanyol, } \\
\text { Toledo, } & \text { Badajoz, } \\
\text { Qurtubah, } & \text { Seville, } \\
\text { Granada, } & \text { Malaga, } \\
\text { Almeria, } & \text { Zaragoza, } \\
\text { Madinah } & \text { Al Zahra, } \\
\text { Tinmal, } & \text { Marakesh, } \\
\text { Maknas, Fas, Tlemcen, } & \text { Tunis, } \\
\text { Algiers, } & \text { Qayrawan, } \\
\text { Monastir, Mahdiyyah, } & \text { Susah, } \\
\text { Stax, } & \text { Tripolli, } \\
\text { Ajdabiyyah, Nedroma, } & \text { Qala'ah, } \\
\text { Hammad, Taza. }\end{array}$ \\
\hline $\begin{array}{l}\text { Wilayah II } \\
\text { (Afrika } \\
\text { Tengah) }\end{array}$ & $\begin{array}{lr}\text { Gao, } & \text { Timbuku, } \\
\text { Goundam, Larabanga, } & \text { Chingueti, } \\
\text { Namou, } & \text { dioulasso, } \\
\text { Bobo, } & \text { Agadez, Kano, Sokoto, } \\
\text { Dakar, Jenne, Zaria, } & \text { Kilwa, } \\
\text { Ilorin, } & \text { Uogadishu, } \\
\text { Durman, Lamu, Siyu, } & \text { Gedi, }\end{array}$ \\
\hline
\end{tabular}




\begin{tabular}{|c|c|}
\hline & $\begin{array}{lr}\text { Mombasa, } & \text { Mnarani, } \\
\text { Kaole, } & \text { Ungwana, } \\
\text { Muhembo, } & \text { Songo, } \\
\text { Mnara, } & \text { Kizimkazi, } \\
\text { Pemba, Suakin. }\end{array}$ \\
\hline $\begin{array}{l}\text { Wilayah III } \\
\text { (Masyriq) }\end{array}$ & $\begin{array}{lr}\text { Kairo, } & \text { Yerusalem, } \\
\text { Damaskus, } & \text { Raqqah, } \\
\text { Aleppo, } & \text { Baghdad, } \\
\text { Anjar, } & \text { Samara, } \\
\text { Mawsli, } & \text { Bashrah, } \\
\text { Qusyar, } & \text { Amrah, } \\
\text { Ramlah, Qasr Al Hayr, } & \text { Musha'ta, } \\
\text { Madinah, } \\
\text { Mekkah, Sana'a. }\end{array}$ \\
\hline $\begin{array}{l}\text { Wilayah IV } \\
\text { ( Turki) }\end{array}$ & $\begin{array}{lr}\text { Edirne, Istanbul, Iznik, } \\
\text { Bursa, Ankara, Konya, } \\
\text { Amasya, } & \text { Siyas, } \\
\text { Divrigi, } & \text { Kaysen, } \\
\text { Erzuum, } & \text { Bilecik, } \\
\text { Eyub, } & \text { Savranbolu, } \\
\text { Birgi, } & \text { Uskudar, } \\
\text { Nevsedir, } & \text { Manisa, } \\
\text { Payas, } & \text { Luleburgaz, } \\
\text { Adilevaz, } & \text { Karapinar, } \\
\text { Aksaray, Nigde, Bey. }\end{array}$ \\
\hline $\begin{array}{l}\text { Wilayah V } \\
\text { ( Iran dan } \\
\text { Asia } \\
\text { Tengah) }\end{array}$ & $\begin{array}{l}\text { Shiraz, Isfahan, } \\
\text { Natans, Kashan, Qum, } \\
\text { Saveh, Rayy, Tehran, } \\
\text { Varamin, Zawari, } \\
\text { Ardistan, Nayin, Yazd, } \\
\text { Kirman, Damghan, } \\
\text { Tabriz, maraghah, } \\
\text { Ardabil, Sultaniyah, } \\
\text { mashad, Turbat-i- } \\
\text { Shaykh, Hamadan, } \\
\text { Bistam, Tus, Sangbast, } \\
\text { Qazwin, Bukhara, } \\
\text { Khiwa, } \\
\text { Samarqand, Marw, } \\
\text { Nakhijawan, } \\
\text { Tashqand, Tirmidh, } \\
\text { Sahr-i-Sabz, Balkh, } \\
\text { Ghaznab, Herat, } \\
\text { Kabul, Bust, Tayabat, } \\
\text { Gazur, Gah, Jam. }\end{array}$ \\
\hline $\begin{array}{l}\text { Wilayah VI } \\
\text { ( mencakup } \\
\text { anak benua } \\
\text { India dan } \\
\text { sebagian } \\
\text { wilayah } \\
\text { muslim ) }\end{array}$ & $\begin{array}{l}\text { Lahore, Thatha, } \\
\text { Uchch, Multan, Delhi, } \\
\text { Agra, Fatehpur, Sikr, } \\
\text { Ajmir, Ahmadabad, } \\
\text { Bhopal, Mandu, } \\
\text { Bijapur, Banaras, } \\
\text { Juanpur, Khandesh, } \\
\text { Champanir, } \\
\text { Tughluqabad, }\end{array}$ \\
\hline
\end{tabular}

\begin{tabular}{|l|l|}
\hline & $\begin{array}{l}\text { Sasaram, Jahanpana, } \\
\text { Shahjamambad, } \\
\text { Tribeni, Chhota, } \\
\end{array}$ \\
& Pandua, Bagerhat, \\
& Rampal, Malda, dacca, \\
& Sura, Sherpur, \\
& Rajmahal, Hazrat, \\
& Pandua, Gaur \\
\hline Wilayah VII & Turfan, Xian, Kuala \\
(Asia Timur & Lumpur, Kuala \\
dengan & Kangsar, Malacca, \\
populasi & Kota Baru, Duria, \\
muslim & Burung, \\
mayoritas ) & SEMARANG, \\
& DEMAK, BANDA \\
ACEH, JAKARTA, & SOLO, Marawi, City \\
& Job, Bandar Seri \\
& Begawan, \\
Singapore,Seoul. \\
\hline
\end{tabular}

Tabel 1: persebaran kaligrafi dari barat ke timur pada abad ke tujuh sampai abad ke dua puluh

\section{Pembahasan}

\section{Sejarah Kaligrafi Arab}

Pembentukan huruf abjad Arab pada masa awal Islam hingga dikenal ke berbagai wilayah memakan waktu berabad-abad. Inskripsi Arab Utara bertarikh $250 \mathrm{M}, 328 \mathrm{M}$ dan $512 \mathrm{M}$ menunjukkan kenyataan tersebut. Inskripsi-inskripsi yang ada, dapat ditelusuri bahwa huruf Arab berasal dari huruf nabati yaitu huruf orang-orang Arab Utara yang masih dalam rumpun Semit yang terutama hanya menampilkan hurufhuruf mati. Dan dari masyarakat Arab utara yang mendiami Hirah dan Anbar tulisan tersebut berkembang pemakaiannya ke wilayah-wilayah selatan jazirah Arab. (http://anshar-mtk.blogspot.com/.../sejarahperkembangan-kaligrafi-islami.html)

Salah satu aspek yang menjadi perhatian para pemerhati kebudayaan Arab adalah upaya menghidupkan warisan budaya Arab (turāts al-'arabī) berupa kaligrafi. Sejak abad ketiga hijriyah yaitu abad penting kebangkitan tradisi Arab ini satu hal yang tidak bisa dilupakan adalah jasa Ibnu Muqlah dalam mengembangkan tulisan kufi ke dalam tulisan Arab, kemudian dilanjutkan para penerusnya seperti Ibnu Abd Salam, Ibnu Bawwab dan lain sebagainya. (Zainuddin, 2009: I/1) 
Bagaimana kaligrafi ini sampai di Indonesia adalah pertanyaan penting dalam memahami persebaran budaya Arab karena cabang seni ini memberikan pengaruh besar bagi kehidupan sosial, politik, pendidikan di Indonesia.

\section{Kaligrafi Arab di Indonesia}

Indonesia di sebut-sebut Al Faruqi menjadi wilayah yang sangat asimilatif terhadap perkembangan seni kaligrafi. Di kota-kota seperti Solo, Semarang, Demak, Jakarta, dan Banda Aceh tempat di mana persebaran agama Islam menguat, buktibukti artefak dengan mudah ditemukan. Adalah suatu kekhasan bagi dunia timur dalam menunjukkan kebudayaannya, bahkan keberadaannya tetap fungsional bersamaan dengan perkembangan modern saat ini.

Salah satu jenis kaligrafi yang paling menonjol di Indonesia adalah kaligrafi Arab, seringkali disebut sebagai kaligrafi islam karena agama ini dinisbahkan kemunculannya di dunia Arab. Dalam sudut budaya, kaligrafi dikenal dengan sebutan khat, rasm, kitabah, raqm, sathr, dan lain sebagainya. Semua merujuk pada makna budaya, yaitu sebuah artefak budaya yang mencakup pengertian, gagasan, sosial dan wujud konkret yang menempel pada sebuah benda dengan tujuan komunikasi sosial-kebahasaan dan keindahan.

Kesenian Islam di Indonesia tidak terbatas pada ciri-ciri visual, namun ciri ini menjadi sesuatu yang khas karena bentuk dan substansi makna yang dikandung di dalamnya. Kaligrafi adalah salah satu dari kesenian-kesenian visual islam yang menonjol di dalam tradisi seni islam sepanjang sejarahnya. Namun demikian dalam perkembangan kaligrafi Arab sesungguhnya tidak bisa dilepaskan dari perkembangan bahasa dan budayanya. Bahasa Arab menjadi faktor utama bagi perkembangan tradisi tulisan Arab sebagaimana tradisi oral bahasa itu ke dalam berbagai dialek. Tradisi tulisan arab juga mengalami proses atau pengaruh domestikasi (al-atsar al-machallī) (Al Jabbury, 1994: 14) sesuai dengan situasi kesejarahannya. Di Indonesia, perkembangan seni tulis Arab itu ditemukan sejarahnya bersamaan dengan proses masuknya Islam dan dakwah yang dilakukan oleh para ulama. Hal itu menjadi salah satu sebab utama persebaran kaligrafi Arab ke wilayah Asia dan ekses dari tersebarnya warisan budaya arab dan ajaran agama Islam (dakwah islamiyah), proses penyebaran ajaran agama dalam wujud gagasan, pemikiran dan seni yang bersumber dari kitab suci dan hadis melibatkan aktifitas budaya, yaitu tradisi tulis dan lisan dengan bahasa arab sebagai medium utama dan Al-Quran sebagai sumber materi. Dalam perkembangannya, tradisi menulis Arab atau melukis kaligrafi menjadi sejarah yang terus berlangsung di dalam aktivitas budaya, seni, dan pendidikan, kaligrafi menjadi pelajaran atau mata kuliah yang diajarkan di madrasah, sekolah, dan perguruan tinggi. Di luar lembaga pendidikan formal kaligrafi juga menjadi bagian dari tradisi budaya yang setiap saat digagas, diproses dan dicipta oleh para seniman dan praktisi.

Memasuki abad ke dua puluh ruangruang ekspresi kaligrafi semakin luas, kecenderungan untuk melibatkan berbagai disiplin ilmu lain dalam bentuk simbiosis juga terbuka, bahkan dengan terbukanya jendela dunia, kaligrafi masuk dan melebur dalam ruang publik yang luas, unsur-unsur zoomorfik bertanasukh atau berreinkarnasi ke dalam kaligrafi Arab dengan berbagai ekspresi di dalamnya. Wujud ekspresi itu antara lain, ekspresi mimetik, yaitu penampakan yang diarahkan untuk sekedar meniru atau memodifikasi realitas bentuk hewan tanpa stilisasi atau perubahanperubahan bentuk yang mengandung unsur hikmah. Ekspresi kreatif dimaksudkan sebagai hiasan untuk mengisi atau melengkapi ruang-ruang kosong di sekitar tulisan kaligrafi sehingga nampak unsur artistik dari tulisan itu, sebagai ekspresi estetik dimaksudkan untuk menyampaikan gagasan-gagasan, misi dan keindahan dari dunia di dalam diri maupun ide-ide yang dipetik dari ajaran, hikmah, dan tradisitradisi kesenian, dan sebagai ekspresi simbolik dimaksudkan untuk menangkap makna-makna dari eksistensi, karakter, dan status hewan yang digali dari amsal-amsal dalam Al-Quran. (Yahya, 2000: 130)

Dalam sejarahnya kaligrafi sebagai seni tidak semata sebuah karya kreatif, ia memerlukan kajian, metode, maupun 
pendekatan, dan sebagai kreatifitas ia juga tidak sekedar memerlukan keterampilan dan pembiasaan, namun juga membutuhkan filosofi dan kontemplasi untuk membentuk paradigma kesenian yang utuh. Sudah muncul upaya memahami kaligrafi sebagai objek kajian, bukan lagi sebagai seni dua dimensi, tetapi melalui disiplin ilmu kaligrafi kajian bidang ini digunakan sebagai sebuah pendekatan transformasi untuk menemukan sebuah konsep bangunan. (Amiuza, dkk, 2012: 1-6)

\section{Kaligrafi sebagai Kreativitas Estetis}

Di luar peran sosial masyarakat yang tinggi terhadap budaya kaligrafi, aktivitas menulis indah merupakan naluri estetis yang muncul karena dorongan nilai-nilai keindahan manusia sebagai Homo Aestheticus, yaitu makhluk yang mengerti akan keindahan. Sebagai makhluk yang memiliki naluri estetis ini aktifitas melukis dan menulis indah merupakan bentuk kesempurnaan jati diri yang dilahirkan oleh manusia. "The written word is a talisman, and the process of writing is a magic connected not only with the master's technique and skill, but also with his spiritual and moral character." "Kata-kata tertulis adalah jimat, dan proses menulis adalah sihir terhubung tidak hanya dengan master teknik dan keterampilan, tetapi juga dengan rohani dan moral karakter." www.ndukhan.com/

Dalam ajaran Islam apresiasi terhadap seni menyentuh berbagai aspek, antara lain aspek jasmaniyah-lahiriah dan spiritual-batiniah. Keindahan lukisan dan tulisan paralel dengan keindahan alam, yang juga paralel dengan keindahan agama. Mengenai hal itu Alquran mengisyaratkan tentang simbolisme keindahan itu dalam surah An-Nahl ayat 6, “ Dan kamu memperoleh pandangan yang indah padanya, ketika kamu membawanya kembali ke kandang dan ketika kamu melepaskannya ke tempat penggembalaan." Sebuah pandangan naturalistik yang dipersepsikan secara metafisis dengan menghadirkan gagasan tentang alam. Di sini Al-Quran menunjukkan bahwa keindahan itu bersifat alami namun kehadirannya juga merupakan fakta naqli.
Kaligrafi sebagai fakta estetik dapat ditunjukkan pada kecenderungan fungsional tulisan arab sebagai seni, yaitu seni tulisan yang menekankan keindahan sebagai unsur utama di dalam aktifitas budaya. Namun ia juga merupakan sebuah karya dari ide-ide dan perasaan yang dituangkan lewat kepiawaian tangantangan para khaththat pada artefak, manuskrip, bangunan, seni tekstil, dan lain-lain." handwriting is the tongue of the hand, style is the tongue of the intellect. The intellect is the tongue of good actions and qualities. And good actions and qualities are the perfection of man. " Tulisan tangan adalah lidahnya tangan, gaya adalah lidahnya intelek. Dan intelek adalah lidahnya tindakan yang baik dan kualitas. Dan tindakan yang baik dan kualitas adalah kesempurnaan manusia. (Rosenthal, 1971: 34.)

Berpijak pada kata-kata itu, nampaknya para khaththat Indonesia memanfaatkan berbagai macam media agar seni ini terkesan fleksibel dalam menghadapi perubahan zaman, selain itu untuk menunjukkan sublimitas yang muncul dari dimensi eksoterik maupun esoteriknya, yaitu tulisan sebagai kulit luar dan makna kata sebagai bagian dalamnya, Dengan demikian kaligrafi ini dapat dikukuhkan sebagai seni yang sublime.

\section{Kaligrafi sebagai Aktifitas budaya, Sosial, dan Agama.}

Kesenian Arab tidak terbatas pada ciriciri visual, namun ciri ini menjadi sesuatu yang khas karena bentuk dan substansi makna yang dikandung di dalamnya. Kaligrafi Arab Islam adalah salah satu dari kesenian-kesenian visual islam yang menonjol di dalam tradisi seni islam sepanjang sejarahnya. Namun demikian, perkembangan kaligrafi Arab sesungguhnya tidak bisa dilepaskan dari perkembangan bahasa dan budayanya. Bahasa Arab menjadi faktor utama bagi perkembangan tradisi tulisan arab sebagaimana tradisi oral bahasa itu ke dalam berbagai dialek.

Di Indonesia, perkembangan seni tulis arab itu ditemukan sejarahnya bersamaan dengan proses masuknya islam dan dakwah yang dilakukan oleh para ulama. Peninggalan berupa karya pemikiran dan 
ajaran maupun artefak menunjukkan adanya bukti-bukti budaya tulisan berbahasa arab. Tulisan arab dalam wujudnya yang genuine mempunyai arti kaligrafi sebagaimana selama ini dipahami sebagai seni keindahan tulisan, hal ini dapat dibuktikan bahwa dalam berbagai macam peninggalan seni budaya arab, terutama menyangkut tradisi tulisan di Indonesia adalah data ditemukannya pada batu nisan makam Fatimah binti Maimun di Gresik (wafat 495 H/1082 M) (Syukur, 2012: 193), dan juga adanya bukti mata uang dirham yang bertuliskan "Al A'la" dan disampingnya tertulis "Sultan" pada dinasti kerajaan Perlak di Sumatera. (Syukur, 2012: 202) dan beberapa makam lainnya dari abad-abad ke-15 yang ditandai dengan penulisan batu nisan pada makammakam, huruf Arab, disamping tulisantulisan materi pelajaran, catatan pribadi, undang-undang, naskah perjanjian resmi dalam bahasa setempat, dalam mata uang logam, stempel, kepala surat, dan sebagainya. Huruf Arab yang dipakai dalam bahasa setempat tersebut diistilahkan dengan huruf Arab Melayu, Arab Jawa atau Arab Pegon. (https://hilyatulqalam.wordpress.com/.../sej arah-perkembangan-kaligrafi-)

Tulisan arab sebagaimana dikemukakan di dalam fakta penyebaran Islam merupakan bukti bahwa tradisi skriptural di Indonesia menandai wujud perkembangan kaligrafi yang sudah matang. Hal itu terbukti dengan adanya benda-benda yang tersebar di dalam berbagai media seperti batu nisan, gapura, naskah-naskah kuno, lempenganlempengan benda dari perunggu, logam dan sebagainya. Bukti-bukti itu masih menunjukkan adanya kaligrafi sebagai tulisan. Pada tahap selanjutnya tulisan arab menempati perannya sebagai seni dua dimensi yang tampak pada mihrab, kubah, dinding, pintu dan jendela serta ruangruang kosong menjadi media yang khas bagi kaligrafi. Kekhasan yang nampak menjadi simbol budaya keagamaan islam di berbagai wilayah negeri muslim termasuk di Indonesia pada umumnya.

Perkembangan kaligrafi di masa sekarang menunjukkan adanya kemajuan terkait dengan perkembangan paradigma dan fungsi kesenian itu dalam berbagai ranah. Kaligrafi arab tidak sekedar berfungsi memenuhi kebutuhan estetis dalam ranah sosial keagamaan tetapi sudah masuk ke bidang lain (arsitektur) yang disesuaikan dengan trend gaya hidup masyarakat dan kebutuhan pasar. Perkembangan teknologi media juga menawarkan sarana akses secara lebih cepat dan baru meskipun media konvensional terus digunakan sebagai kebutuhan visual yang tidak bisa ditinggalkan. Secara teknis penggunaan bahan logam seperti stainless, perunggu, dan kuningan menimbulkan kesan elegan dan mewah, bahan-bahan tersebut sangat cocok dipakai untuk papan nama luar ruangan maupun dalam ruangan yang bergaya minimalis baik masjid, mushola, rumah, sekolah, rumah sakit, kantor dan lainnya Bahan yang dipakai adalah lempengan baja putih atau platlesser yang dipotong dan dipatri dengan bentuk model 3

(www.pesantrenkaligrafipskq.com)

Penggunaan bahan GRC atau Glassflore Reinforced Cement, sebuah rekayasa pengganti produk-produk sejenisnya karena dapat diaplikasikan untuk menutup dinding/bangunan lama dan atau bangunan baru merupakan alternatif lain dalam pengembangan bahan. www.assirygrckubah.com

Di Indonesia kaligrafer arab yang telah berhasil menorehkan karya-karya besar kaligrafi membuktikan bahwa mereka telah menunjukkan sumbangan besar peradaban arab Islam antara lain H D Sirojuddin, Amri yahya, A.D. Pirous, dan sederetan nama-nama kaligrafer kondang lainnya. Bahkan tulisan mereka menjadi bahan pelajaran bagi yang ingin mendalami bidang ini, buku tentang kaligrafi islam karya Sirodjudin misalnya, merupakan buku Ensiklopedia Kaligrafi Islam pertama di Indonesia yang memuat kumpulan karya master kaligrafi, baik dunia maupun Indonesia. Dibandingkan buku-buku kaligrafi yang pernah terbit sebelumnya buku ini menawarkan data karya dan penulisnya secara lebih lengkap, disertai pembagian jenis kaligrafi secara lebih detail. Cocok dijadikan salah satu bahan referensi belajar dan penelitian tentang kaligrafi. 
Aktifitas budaya islam yang ditunjukkan di dalam even Musabaqah Tilawatil Quran di Indonesia mengangkat kaligrafi arab islam menjadi momentum penting dalam dakwah kesenian. Kaligrafi bukan sekedar kesenian tulis menulis melainkan pesan yang membawa moral, iman, dan dakwah. Meskipun tujuan ini digunakan oleh orang-orang non muslim untuk menyebarkan misi mereka sebagaimana nampak dalam kaligrafi berikut ini.

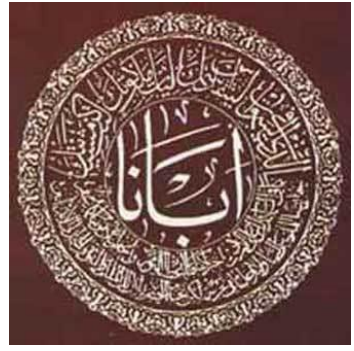

Kaligrafi melingkar ukuran setengah meter persegi ini bagian tengahnya bertuliskan "abana" yang berarti "bapa kami”. Dalam teologi Kristen, kata ini berarti Allah (Allah Bapak). Bila dibaca dengan teliti, maka bacaan yang lengkap adalah "abana alladzi fis-samawati, Bapa kami yang ada di langit. dst". http://www.swaramuslim.com Hati-Hati Kaligrafi Kristiani Dijual Bebas). Kaligrafi ini jelas menunjukkan adanya pesan dari luar ajaran Islam, dan jika orang tidak mengerti tulisan kaligrafi dan makna yang tersurat di dalamnya dia akan beranggapan bahwa tulisan itu adalah kaligrafi islam yang ditulis orang-orang islam, oleh karena itu harus dibedakan antara kaligrafi arab dan kaligrafi islam.

\section{Kesimpulan}

Kaligrafi sebagai sebuah ide pemikiran nampaknya jarang ditulis namun sebagai sebuah aktifitas sosial budaya dalam wujud artefak sudah menjadi bagian yang sangat popular di kalangan masyarakat di Indonesia. Sebagai objek gagasan, kaligrafi memerlukan langkah-langkah progresif menuju masa depan seni akulturatif yang yang mampu beradaptasi dalam berbagai bentuk kesenian visual yang luas.

Di Indonesia kaligrafi Arab merupakan hasil persebaran dari tradisi khat, rasm, kitabah, raqm, atau Satr di Timur Tengah. Kaligrafi ini mengalami perkembangan pesat seiring dengan penerimaan masyarakat Indonesia terhadap tradisi, budaya, khususnya agama Islam yang menjadi basis kesenian itu. Perkembangan itu juga ditandai dengan perubahan paradigma seni yang terus bergerak mengikuti alur sejarah dan peran bidangbidang lain yang bisa memanfaatkan kaligrafi sebagai unsur estetis.

\section{Daftar Pustaka}

Ahimsa-Putra, Heddy Shri. Paradigma dan Revolusi Ilmu Dalam Antropologi Budaya. Hal. 9. Dan juga dalam: David Kaplan dan Robert A. Manners, Teori Budaya, ... hlm. 11. Akses 2 Maret 2016

Al Faruqi, Ismail Raji. 1986. The Cultural Atlas of Islam. New York: Macmillan Publishing Company.

Al Jabbury, Yahya Wahib. 1994. Al Khaththu wal Kitabatu fil Hadharaatil Arabiyyati. Beirut: Dar al-Gharb al-Islami.

Amiuza, Chairil B., Harini Subekti dan Livie Sukma Taristania. 2012. Pendekatan Transformasi Bentuk Kaligrafi sebagai Konsep Desain Pusat Pengembangan seni Kaligrafi Islam. http://publikasiilmiah.ums.ac.id/../. Hlm. 1-6.

Anshar-mtk.blogspot.com/.../sejarahperkembangan-kaligrafiislami.html. Diakses pada selasa, 12 April 2016.

Assirygrckubah.com. Akses 16 Maret 2016

Pesantrenkaligrafipskq.com. Download Buku Kaligrafi. Akses 16 Maret 2016.

Roedijambi.wordpress.com/.../teorievolusi-dan-difusi-kebudayaanm. Analisis komparatif terhadap dua paradigma dalam antropologi. dikutib dari Made Titib.blogspot.com. Akses 2 Maret 2016.

Rosenthal, F. 1971. Four Essays on Art and Literature in Islam. Leiden: E J Brill 
Sarwono.blogspot.com > Budaya. Akses, 3 Maret 2016.

Sejarah Penyebaran Islam.blogspot.com/2015/10/kaligra fi-s.html. Akses 2 Maret 2016.

Syukur, Fatah. 2012 . Sejarah Peradaban Islam. Semarang: PT. Pustaka Rizki Putra.

Swaramuslim.com : Hati-Hati Kaligrafi Kristiani Dijual Bebas.

http://www.swaramuslim.com/di akses pada Senin 18 April 2016.

Yahya, Amri. Unsur-unsur Zoomorfik dalam Seni Rupa Islam, Al jami'ah, No 65/VI/ 2000, hlm. 130

Zainuddin, Najiy. 2009. Mushawwirul Khaththi l' Arabiy. Beirut: Dar al Ma'rifah. 